\title{
Polyculture of mullets in brackishwater using compounded feed: proximate and mineral profiles in comparision with wild mullets
}

\author{
J. SYAMA DAYAL*, K. AMBASANKAR, R. JANNATHULLA, K. P. KUMARAGURUVASAGAM, \\ M. KAILASAM AND K. K. VIJAYAN \\ ICAR-Central Institute of Brackishwater Aquaculture, 75, Santhome High Road, R. A. Puram, Chennai - 600028 \\ Tamil Nadu, India \\ e-mail:syamdayal@rediffmail.com
}

\begin{abstract}
Two stage rearing (nursery and grow-out) of two mullet species, Mugil cephalus and Liza parsia was demonstrated in a farmer's pond. In the nursery phase, wild collected grey mullet $(1.65 \pm 0.2 \mathrm{~g})$ and gold spot mullet $(1.03 \pm 0.1 \mathrm{~g})$ fry numbering 450 and 4000, respectively were stocked in pen enclosures. After 30 days of nursery rearing, they were released into the same pond and reared for 7 months using dry pelleted feed produced in the feed mill of ICAR-Central Institute of Brackishwater Aquaculture (ICAR-CIBA), Chennai. Feed was formulated using locally available ingredients to contain $33.4 \%$ crude protein and 5.7\% ether extract. The fishes were fed with crumbles $(0.8 \mathrm{~mm})$ and pellets $(2$ and $3 \mathrm{~mm})$ in the nursery and grow-out phases, respectively. The production of both the mullet species together at harvest was $1262 \mathrm{~kg} \mathrm{ha}^{-1}$ (L. parsia 851 and M. cephalus, $411 \mathrm{~kg} \mathrm{ha}^{-1}$ ). The nutrient composition of the two farmed sympatric mullet species when compared with their respective wild samples showed a significant variation. Higher lipid content in the farmed fishes was observed compared to their respective wild originates. The effect of size was highly significant in lipid content, its value increasing proportionately with size $(\mathrm{p}<0.05)$ in both wild and cultured fishes. Cultured $M$. cephalus contained significantly $(\mathrm{p}<0.05)$ higher levels of $\mathrm{Ca}, \mathrm{K}, \mathrm{Mn}, \mathrm{Cu}$ and $\mathrm{Zn}$, while wild M. cephalus had significantly $(\mathrm{p}<0.05)$ higher concentrations of $\mathrm{Na}$ and Fe. The wild collected L. parsia had significantly $(\mathrm{p}<0.05)$ higher mineral content compared to the cultured fishes. The dietary value (DV\%) of mullets indicates that consumption of $100 \mathrm{~g}$ fish could meet the daily requirements of $\mathrm{Ca}$ and $\mathrm{P}$ for adult human being. Mullet could provide $60-75 \%$ of dietary value for Se, which is an important micronutrient that plays a major role in scavenging the free radicals due to its anti-oxidative properties. The results of this study demonstrated the techno-economic viability of mullet culture in farmer's pond. Mullets are an ideal choice for diversification of brackishwater aquaculture and could serve as an alternative livelihood source and nutritional security for the coastal population.
\end{abstract}

Keywords: Mineral composition, Mullets, Polyculture, Proximate composition

\section{Introduction}

Coastal aquaculture, synonymously known as "brackishwater aquaculture" is a rapidly expanding agro-industry which plays an important role in coastal livelihood and seafood production in India. Farming of shrimp continues to form the bulk of aquaculture activity in brackishwater sector, but for further sustainable growth, there is a need for diversification. Subsequent to failures in shrimp culture, some of the farmers are showing interest in polyculture of brackishwater finfishes. The concept of polyculture is based on the fact that culturing of two or more compatible aquatic species together in the same space will result in higher productivity compared to monoculture (Eldani and Primavera, 1981; Milstein, 2005). It is dominant mainly in Asia, providing a sustainable livelihood and source of nutrition (FAO, 2012). Traditional brackishwater polyculture was generally practiced in large impoundments known as 'bherries' in India (Lovatelli, 1990), ghers in Bangladesh (Shofiquzzoha et al., 2001) and pond based systems in the Philippines (Aubin et al., 2015). Polyculture of mullets with tiger shrimp was successfully demonstrated in the farm of ICAR-Central Institute of Brackishwater Aquaculture (ICAR-CIBA) at Kakdwip, West Bengal (Biswas et al., 2012).

Mullets, belonging to the family Mugilidae, are potential candidate species for brackishwater farming due to the commercial value and tolerance to wide range of temperature and salinity (Young and Potter, 2002; Cardona, 2006; Gonzalez-Murcia et al., 2012). In many countries, grey mullet, Mugil cephalus is an important aquaculture species for its highly valuable roe and is called "grey gold". Another mugilid, Liza parsia (Ham.), commonly called gold spot mullet is a catadromous fish. Both the species are widely distributed in the coastal waters of tropical and sub-tropical regions extending from $42^{\circ} \mathrm{N}$ to $42^{\circ} \mathrm{S}$ 
(Nash and Shehadeh, 1980; Talwar and Jhingran, 1991). Feeding habits of mullets make them ideal species for polyculture in association with other fish and crustaceans. Recent isotopic studies on gut contents showed that gold spot mullet was not a competitor for food with grey mullet (Le Loc'h et al., 2015). Most of the earlier polyculture studies were conducted with shrimp or mud crab as one of the high valued species, along with finfishes (Shofiquzzoha et al., 2001; Biswas et al., 2012). Considering this eco-biological facts and the economic importance of these mullets, an "onfarm trial" was conducted on polyculture of grey mullet and gold spot mullet, using formulated pelleted feed in an abandoned shrimp farm after partial renovation. As a different approach, a two stage rearing (nursery and grow-out) was attempted to have good control over feed management and handling of juvenile fishes. Nutrient and mineral composition of both cultured and wild mullets were analysed to understand whether the nutritional quality of cultured fishes are equivalent or superior, which is an important determinant for acceptability of the farmed fish by the consumers as the nutrient composition vary greatly from species to species, as well as from individual to individual of the same species due to differences in size, season, location, habitat, gender, age and source of collection i.e., wild or cultured (Alasalvar et al., 2002; Grigorakis et al., 2002; Fuentes et al., 2010). The availability of reliable nutritional data base of wild and cultured fish species not only helps in nutritional labelling and processing, but also forms the base for dietary prescriptions.

\section{Materials and methods}

\section{Culture trial}

The culture demonstration was conducted in an abandoned brackishwater shrimp pond of 0.35 ha in Nagayalanka, Diviseema region of Krishna District, Andhra Pradesh, India $\left(15.945^{\circ} \mathrm{N}\right.$ and $\left.80.918^{\circ} \mathrm{E}\right)$. The pond was sun dried and lime $(\mathrm{CaO})$ was applied to the pond bottom at $500 \mathrm{~kg} \mathrm{ha}^{-1}$. After one week, it was filled with filtered brackishwater from nearby Krishna River, to a depth of $70 \mathrm{~cm}$. Subsequently, on $9^{\text {th }}$ day, the pond was fertilised with organic manure, cattle dung and inorganic fertilisers, urea and single super phosphate (SSP) at 2000, 50 and $50 \mathrm{~kg} \mathrm{ha}^{-1}$, respectively and allowed for a week for the growth of natural fish food organisms (Biswas et al., 2012). Inside the pond, three pen enclosures each measuring $4 \mathrm{~m}^{2}(2 \mathrm{~m} \times 2 \mathrm{~m})$ were built using nylon net of $2 \mathrm{~mm}$ knot to knot mesh. Mullet fry collected from shallow tidal pools in the nearby backwaters were brought in buckets and sorted for species and size. Uniform sized grey mullet $(1.65 \pm 0.2 \mathrm{~g})$ and gold spot mullet fry $(1.03 \pm 0.1 \mathrm{~g})$ numbering 450 and 4000 respectively were stocked in pen enclosures. Grey mullet seeds were stocked in one pen and gold spot mullets were stocked in two pens (a) 2000 per enclosure. After 30 days of nursery rearing, the survival and average size of the fish was recorded. Juveniles of mullets (350 nos. of M. cephalus and 3700 nos. of $L$. parsia) were released into the same pond and cultured together for 7 months. After completing the nursery period, the pond water level was increased to $>1.2 \mathrm{~m}$ and this level was maintained throughout the culture period. The evaporative and seepage losses were compensated and water exchange was done at $20 \%$ of the total pond water on a monthly basis. The pond soil and water quality parameters were measured once in two months for important parameters like salinity, $\mathrm{pH}$, dissolved oxygen, temperature, total alkalinity, total ammonia-nitrogen $\left(\mathrm{NH}_{3}-\mathrm{N}\right)$, nitrite-nitrogen $\left(\mathrm{NO}_{2}-\mathrm{N}\right)$, nitrate-nitrogen $\left(\mathrm{NO}_{3}-\mathrm{N}\right)$ and phosphate-phosphorus $\left(\mathrm{PO}_{4}-\mathrm{P}\right)$ following standard procedures (APHA, 2012). On termination, the fish were harvested using drag net and by handpicking after completely draining the pond water. The final biomass $\left(\mathrm{kg} \mathrm{ha}^{-1}\right)$, average body weight $(\mathrm{g})$, survival (\%) and daily weight gain of both the species of mullets were calculated.

\section{Feed preparation and feed management}

Compounded sinking pellets were produced in the ICAR-CIBA pilot scale feed mill, Muttukadu, Chennai. All the coarse ingredients were powdered in two stages by grinding in hammer mill and micropulveriser and passed through $0.5 \mathrm{~mm}$ screen. The powder along with the liquid ingredients and the binder was mixed in horizontal ribbon mixture and thoroughly homogenised after adding 31 of water per $100 \mathrm{~kg}$ material. The mash was pelletised in the ring-die pellet mill at $15-16 \%$ moisture and $90^{\circ} \mathrm{C}$ temperature under steam conditioning. The pellets were produced using 2 and $3 \mathrm{~mm}$ die. Crumbles of $0.8 \mathrm{~mm}$ were prepared for nursery feeding. Daily ration was distributed in four and two equal meals during nursery and grow-out periods, respectively. The quantity of feed was adjusted by fortnightly sampling and assumed survival percentage of 85 in grow-out culture.

\section{Fish samples for nutrient and mineral analysis}

The salinity of the pond water and the area in Krishna River from where wild fish sample collection was made ranged between 10 and 22\%o. The fishes were collected from the pond and river at regular intervals until harvest in such a way as to have three size groups (50-100 g, $101-150 \mathrm{~g}$ and $>150 \mathrm{~g}$ for L. parsia and 100-250 g, 251-500 $\mathrm{g}$ and $>500 \mathrm{~g}$ for $M$. cephalus) in both cultured and wild systems. They were dressed by descaling and degutting. Except the head and tail portion of the fish, the remaining portions were cut into pieces and macerated along with skin and spines for further analysis. Triplicate samples 
from each group (5-8 fishes) of wild and cultured fish were stored at $-20^{\circ} \mathrm{C}$ until analysis. Harvested fish samples with six replications were used for mineral analysis.

\section{Laboratory analysis}

The nutrient composition of fish feed and fish tissue samples was determined following standard methods (AOAC, 1997). Minerals in the fish samples were analysed after digestion with Anton-Par microwave system using nitric acid and hydrochloric acid. The contents were

Table 1. Ingredient, proximate and mineral composition of the feed used for polyculture of mullets in brackishwater pond

\begin{tabular}{|c|c|}
\hline \multicolumn{2}{|c|}{ Ingredient composition ( $\%$ fed basis) } \\
\hline Fishmeal $^{1}$ & 10.0 \\
\hline Acetes & 7.0 \\
\hline Prawn head & 8.0 \\
\hline Soybean meal & 18.0 \\
\hline Groundnut oil cake & 12.0 \\
\hline Gingelly oil cake & 7.0 \\
\hline Broken rice & 7.0 \\
\hline Wheat & 17.5 \\
\hline Rice bran & 8.0 \\
\hline Fish oil ${ }^{1}$ & 1.5 \\
\hline Lecithin & 1.0 \\
\hline Vitamin and mineral mixture $^{2}$ & 2.0 \\
\hline Binder $^{3}$ & 1.0 \\
\hline \multicolumn{2}{|c|}{ Proximate composition ( $\%$ fed basis) } \\
\hline Moisture & 8.23 \\
\hline Crude protein & 33.40 \\
\hline Ether extract & 5.70 \\
\hline Crude fibre & 3.80 \\
\hline Nitrogen free extract ${ }^{4}$ & 37.00 \\
\hline Total ash & 11.87 \\
\hline \multicolumn{2}{|l|}{ Mineral composition (mg $100 \mathrm{~g}^{-1}$ ) } \\
\hline $\mathrm{Ca}$ & 1599.20 \\
\hline $\mathrm{P}$ & 980.60 \\
\hline $\mathrm{Na}$ & 707.50 \\
\hline K & 682.90 \\
\hline $\mathrm{Mg}$ & 405.73 \\
\hline $\mathrm{Cu}$ & 2.68 \\
\hline $\mathrm{Zn}$ & 4.57 \\
\hline $\mathrm{Se}$ & 0.10 \\
\hline \multicolumn{2}{|c|}{$\begin{array}{l}\text { 'Bismi Fisheries, Mayiladuthurai, Tamil Nadu, India } \\
{ }^{2} \text { Commercially sourced pre-mix and each kg contains: Vitamin A } \\
\text {-2000000 IU, Vitamin D } 400000 \text { IU, Vitamin E-300 U, Vitamin } \\
\text { K-450mg, Riboflavin- } 800 \mathrm{mg} \text {, Pantothenicacid-1g, Nicotinamide } \\
-4 \mathrm{~g} \text {, Vitamin B12 - } 2.4 \mathrm{mg} \text {, Choline chloride }-60 \mathrm{~g}, \mathrm{Ca}-300 \mathrm{~g} \text {, } \\
\mathrm{Mg}-11 \mathrm{~g}, \mathrm{I}-400 \mathrm{mg}, \mathrm{Fe}-3 \mathrm{~g}, \mathrm{Zn}-6 \mathrm{~g}, \mathrm{Cu}-800 \mathrm{mg}, \mathrm{Co}-180 \mathrm{mg} \text {, } \\
\text { (Sarabhai Zydus Animal Health Ltd., Vadodara, Gujarat, India) } \\
{ }^{3} \text { Pegabind, Bentoli Agri Nutrition Asia Pvt Ltd, Singapore } \\
{ }^{4} \text { Calculated by difference }\end{array}$} \\
\hline
\end{tabular}

centrifuged at $10000 \mathrm{rpm}$ for $5 \mathrm{~min}$ and filtered by $0.2 \mu \mathrm{m}$ membrane syringe filter in case of turbid filtrate. Mineral contents were determined by ICP-OES (Agilent 5100 VDV). The calibration curve was plotted and checked for linearity at five different concentrations of 2, 4, 6, 8 and $10 \mathrm{mg} \mathrm{l}^{-1}$ with 23 element standard mix (Merck, Cat No: 1.11355.0100). The analytical conditions were maintained at $0.61 \mathrm{~min}^{-1}$ nebuliser flow, $0.21 \mathrm{~min}^{-1}$ auxiliary flow and $151 \mathrm{~min}^{-1}$ plasma flow.

\section{Statistical analysis}

Experimental data with two factors viz., source of fish (wild and cultured) and size group (three size groups) with three levels in each factor were analysed using $2 \times 3$ factorial design. Mineral analysis data was compared by two sample t-test. Descriptive statistical measures (mean \pm standard error) were calculated for the two main factors and their interactions. All the data analyses were done using SPSS version 17.0. The post-hoc analyses were done using least significance difference. Comparison of means was carried out at $5 \%$ significance level $(\mathrm{p}<0.05)$.

\section{Results and discussion \\ Production performance}

The pelleted feed contained 33.4, 5.7, 3.8, 11.87 and $37 \%$ crude protein, crude fat (ether extract), crude fibre, total ash and nitrogen free extract (NFE), respectively (Table 1). The water quality parameters (Table 2) were within the optimum levels for brackishwater finfish culture.

Growth, survival and production data of the two mullet species is presented in Table 3 . Results indicate the ability of the two mullet species to grow in brackishwater

Table 2. Soil and water quality parameters of mullet polyculture pond during the culture trial

\begin{tabular}{ll}
\hline Water parameters & \\
\hline Temperature $\left({ }^{0} \mathrm{C}\right)$ & $30 \pm 1.3$ \\
Salinity $(\% \mathrm{c})$ & $17.5 \pm 5.3$ \\
$\mathrm{pH}$ & $7.85 \pm 0.28$ \\
Dissolved oxygen $\left(\mathrm{mg} \mathrm{l}^{-1}\right)$ & $7.32 \pm 0.6$ \\
Turbidity $(\mathrm{NTU})$ & $12.25 \pm 1.71$ \\
Total alkalinity $\left(\mathrm{mg} \mathrm{l}^{-1}\right.$ as $\left.\mathrm{CaCO}_{3}\right)$ & $133 \pm 10.42$ \\
Total hardness $\left(\mathrm{mg} \mathrm{l}^{-1}\right.$ as $\left.\mathrm{CaCO}_{3}\right)$ & $2394 \pm 943$ \\
Total ammonia N $\left(\mathrm{mg} \mathrm{l}^{-1}\right)$ & $0.199 \pm 0.11$ \\
Nitrite-N $\left(\mathrm{mg} \mathrm{l}^{-1}\right)$ & $0.011 \pm 0.004$ \\
Nitrate-N $\left(\mathrm{mg} \mathrm{l}^{-1}\right)$ & $0.02 \pm 0.008$ \\
Phoshpate-P $\left(\mathrm{mg} \mathrm{l}^{-1}\right)$ & $0.16 \pm 0.08$ \\
\hline Soil parameters & \\
\hline pH & $7.1 \pm 0.05$ \\
Organic carbon $(\%)$ & $0.235 \pm 0.07$ \\
\hline
\end{tabular}


Table 3. Growth and production performance of mullets in polyculture pond

\begin{tabular}{lll}
\hline Performance parameters & Liza parsia & Mugil cephalus \\
\hline Initial weight $(\mathrm{g})$ & $1.03 \pm 0.10$ & $1.65 \pm 0.20$ \\
Final weight after nursery phase $(\mathrm{g})$ & $5.1 \pm 0.46$ & $11.38 \pm 0.76$ \\
Survival after nursery phase (\%) & 92 & 78 \\
Stocking density (nos. ha $\left.^{-1}\right)$ & 10570 & 1000 \\
Final average weight at harvest $(\mathrm{g})$ & $87.64 \pm 15.2$ & $464 \pm 159$ \\
Daily weight gain (g) & 0.36 & 1.92 \\
SGR (\% day $\left.{ }^{-1}\right)$ & 1.85 & 2.35 \\
Survival at harvest $(\%)$ & 92 & 88 \\
Total biomass harvested $\left(\mathrm{kg} \mathrm{ha}^{-1}\right)$ & 851 & 411 \\
\hline
\end{tabular}

pond in a polyculture mode by consuming formulated feed as the major nutrient and energy source. Though the seed of both the mullet species were of almost similar initial weights, the final average weight of $M$. cephalus was almost 5.2 times higher than that of $L$. parsia, indicating significant difference in genetic potential of sympatric mullet species grown under same conditions. Higher growth rate was observed for $M$. cephalus compared to $L$. parsia when reared in polyculture mode with three mullet species viz., M. cephalus, L. parsia and L. Tade, along with tiger shrimp (Biswas et al., 2012). In the present study, daily weight gain (DWG) of 0.36 and 1.92 as well as SGR of 1.85 and 2.35, respectively for $L$. parsia and M. cephalus were higher compared to the results of a farm trial conducted at the Kakdwip Research Centre of ICAR-CIBA (Biswas et al., 2012). This may be due to the longer culture period, less stocking density and lower crude fibre content in the feed used in the present study. The growth performance of both the mullet species based on the periodic samplings is presented in Fig. 1. Mortality of both the mullet species was significantly high in the nursery phase $(9.4 \%)$ compared to the grow-out phase $(7.9 \%)$. This reflects adaptation of the

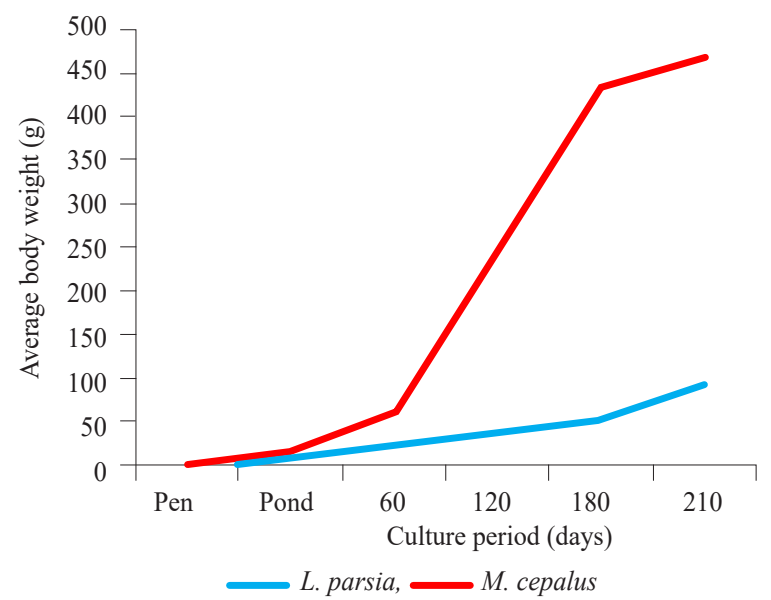

Fig. 1. Growth curve of two sympatric mullet species under same grow-out conditions juveniles to pond environment after initial acclimatisation in pen enclosures.

Production of both the species of mullets together was $1262 \mathrm{~kg} \mathrm{ha}^{-1}$, with production of L. parsia and M. cephalus being 851 and $411 \mathrm{~kg} \mathrm{ha}^{-1}$, respectively. Production was higher than that reported in earlier studies for polyculture systems (Eldani and Primavera, 1981; Shofiquzzoha et al., 2001; Biswas et al., 2012) which might be due to better survival and longer culture period.

\section{Nutritional composition of the mullets}

The high price for even small sized mullets indicates that they are very popular food fish in India. Because of the high demand, most of the fish are sold fresh and the price normally ranges from ₹200 to $250 \mathrm{~kg}^{-1}$. In the present study, proximate analysis (Table 4 and 5) of the two farmed sympatric mullet species showed a significant variation when compared with their respective wild samples, specifically in total lipid content which was higher in the farmed fishes. The effect of size was highly significant on lipid content, its value increasing proportionately with size $(\mathrm{p}<0.05)$ in both wild and cultured fishes. The interactions of source of fish and size were also significantly different $(p<0.05)$. Lipid content of wild mullets was similar to the level reported for Mugil sp. (Karakoltsidis et al., 1995; Menezes et al., 2008). Marais and Erasmus (1977) rated mugilids as "fatty fish" which is also appropriate for farmed mullets in the present study. Higher lipid content of farmed mullets could be mainly attributed to the type of food consumed. Compared to the

Table 4. Nutrient composition ( $\%$ on wet weight basis) of Mugil cephalus of different size groups collected from wild and cultured populations

\begin{tabular}{llll}
\hline $\begin{array}{l}\text { Main effects and } \\
\text { interactions }\end{array}$ & $\begin{array}{l}\text { Crude } \\
\text { protein }\end{array}$ & $\begin{array}{l}\text { Ether } \\
\text { extract }\end{array}$ & $\begin{array}{l}\text { Total } \\
\text { ash }\end{array}$ \\
\hline $\begin{array}{l}\text { Source } \\
\quad \text { Wild }\end{array}$ & $20.19^{\mathrm{a}}$ & $2.47^{\mathrm{b}}$ & $2.51^{\mathrm{b}}$ \\
$\quad$ Cultured & $19.74^{\mathrm{a}}$ & $4.17^{\mathrm{a}}$ & $2.61^{\mathrm{a}}$ \\
Size & & & \\
$\quad$ 100-250 g & $20.22^{\mathrm{a}}$ & $2.04^{\mathrm{b}}$ & $2.38^{\mathrm{c}}$ \\
250-500 g & $19.87^{\mathrm{a}}$ & $3.52^{\mathrm{a}}$ & $2.62^{\mathrm{b}}$ \\
$\quad$ 500 g & $19.80^{\mathrm{a}}$ & $4.41^{\mathrm{a}}$ & $2.68^{\mathrm{a}}$ \\
Source x Size & & & \\
$\quad$ Wild x 100-250 g & $20.26^{\mathrm{a}}$ & $0.53^{\mathrm{c}}$ & $2.26^{\mathrm{e}}$ \\
$\quad$ Wild x 251-500 g & $19.92^{\mathrm{a}}$ & $2.68^{\mathrm{b}}$ & $2.56^{\mathrm{c}}$ \\
$\quad$ Wild x >500 g & $20.37^{\mathrm{a}}$ & $4.22^{\mathrm{a}}$ & $2.72^{\mathrm{a}}$ \\
Cultured x 100-250 g & $20.17^{\mathrm{a}}$ & $3.56^{\mathrm{ab}}$ & $2.50^{\mathrm{d}}$ \\
Cultured x 251-500 g & $19.81^{\mathrm{a}}$ & $4.35^{\mathrm{a}}$ & $2.69^{\mathrm{ab}}$ \\
Cultured x >500 g & $19.23^{\mathrm{a}}$ & $4.61^{\mathrm{a}}$ & $2.65^{\mathrm{b}}$ \\
Pooled SEM $( \pm)$ & 0.120 & 0.324 & 0.0001 \\
\hline
\end{tabular}

Means bearing different superscripts differ significantly $(\mathrm{p}<0.05)$ within main factors (source, size) and interactions 
Table 5. Nutrient composition (\% wet weight basis) of Liza parsia of different size groups collected from wild and cultured populations

\begin{tabular}{llll}
\hline $\begin{array}{l}\text { Main effects and } \\
\text { interactions }\end{array}$ & $\begin{array}{l}\text { Crude } \\
\text { protein }\end{array}$ & $\begin{array}{l}\text { Ether } \\
\text { extract }\end{array}$ & $\begin{array}{l}\text { Total } \\
\text { ash }\end{array}$ \\
\hline $\begin{array}{l}\text { Source } \\
\quad \text { Wild }\end{array}$ & $19.46 \mathrm{a}$ & $1.94 \mathrm{~b}$ & $2.67 \mathrm{a}$ \\
$\quad$ Cultured & $19.49 \mathrm{a}$ & $6.01 \mathrm{a}$ & $2.53 \mathrm{~b}$ \\
Size & & & \\
$\quad 50-100 \mathrm{~g}$ & $19.66 \mathrm{a}$ & $1.99 \mathrm{c}$ & $2.33 \mathrm{~b}$ \\
$\quad 101-150 \mathrm{~g}$ & $19.37 \mathrm{a}$ & $3.95 \mathrm{~b}$ & $2.69 \mathrm{a}$ \\
$\quad>150 \mathrm{~g}$ & $19.39 \mathrm{a}$ & $5.99 \mathrm{a}$ & $2.78 \mathrm{a}$ \\
Source x Size & & & \\
$\quad$ Wild x 50-100 g & $19.86 \mathrm{a}$ & $0.81 \mathrm{e}$ & $2.62 \mathrm{~b}$ \\
$\quad$ Wild x 101-150 g & $19.13 \mathrm{a}$ & $1.91 \mathrm{~d}$ & $2.60 \mathrm{~b}$ \\
$\quad$ Wild x $>150 \mathrm{~g}$ & $19.38 \mathrm{a}$ & $3.11 \mathrm{c}$ & $2.80 \mathrm{a}$ \\
Cultured x 50-100 g & $19.46 \mathrm{a}$ & $3.16 \mathrm{c}$ & $2.04 \mathrm{c}$ \\
Cultured x 101-150 g & $19.62 \mathrm{a}$ & $5.98 \mathrm{~b}$ & $2.77 \mathrm{a}$ \\
$\quad$ Cultured x $>150 \mathrm{~g}$ & $19.41 \mathrm{a}$ & $8.88 \mathrm{a}$ & $2.76 \mathrm{a}$ \\
Pooled SEM $( \pm)$ & 0.494 & 0.070 & 0.006 \\
\hline
\end{tabular}

Means bearing different superscripts differ significantly $(\mathrm{p}<0.05)$ within main factors (source, size) and interactions

natural food such as algae and detritus consumed by wild fishes, the compounded feed offered to the cultured fishes was more nutrient dense (Grigorakis et al., 2002). Further, reduced activity (Alasalvar et al., 2002) compared to wild fish which are also prone to periods of starvation (Haard, 1992) would also have resulted in higher fat in farmed fishes. These results corroborate with the findings of other workers, who compared captive and farmed finfishes (George and Bophal, 1995; Grigorakis et al., 2002; Zhao et al., 2010). In contrast to the present results, Cox and Karahadian (1998) did not find a significant difference in lipid contents of wild and farmed yellow perch.

Positive relationship was observed between fish size and fat content, irrespective of the source and feeding history, indicating that this as intrinsic physiological trait and may also be related to reproductive physiology of the fish (Rheman et al., 2002). Similar observations have been reported in seabass and gilthead bream (Poli et al., 2001; Grigorakis and Alexis, 2005). Morshita et al. (1989) found increased fish muscle lipid values in cultured seabream with increase in size of the fish. Argyrosomus regius contained a lower fat level in the bigger fishes (1600 g) than smaller ones $(830 \mathrm{~g})$ and the authors attributed this to a different lipid metabolism of the fish and the feed offered during farming (Grigorakis et al., 2011; Giogios et al., 2013). The crude protein values were not significantly different between wild and cultured fish in the present study and this finding is in agreement with the earlier reports (Nettlon and Exler, 1992). The wild collected L. parsia had higher total ash values, whereas cultured $M$. cephalus contained higher ash values which may be due to the size and species differences.

Minerals play an important role in human metabolism (Belitz et al., 2008). Minerals present in food can be essential, non-essential or toxic to human beings. Lack of essential minerals in the diet may lead to improper enzyme-mediated metabolic functions, organ malfunctions, chronic diseases and ultimately death. Minerals might have an influence on fillet flavour, thus increasing the importance on mineral comparisons between wild and farmed fish. Mineral content of mullets was affected by the source of collection (Fig. 2). Cultured $M$. cephalus contained significantly $(\mathrm{p}<0.05)$ higher levels of $\mathrm{Ca}, \mathrm{K}, \mathrm{Mn}, \mathrm{Cu}$ and $\mathrm{Zn}$, while wild $M$. cephalus had significantly $(\mathrm{p}<0.05)$ higher concentrations of $\mathrm{Na}$ and $\mathrm{Fe}$. Wild collected L. parsia contained significantly $(\mathrm{p}<0.05)$ higher mineral content compared to cultured fishes. Selenium concentration did not differ $(p>0.05)$ between wild and farmed fish of both the species. Cultured yellow perch contained higher $\mathrm{Mg}, \mathrm{P}$ and $\mathrm{K}$, while wild samples had significantly higher concentrations of $\mathrm{Na}(\mathrm{p}<0.05)$. Significantly higher concentrations $(\mathrm{p}<0.05)$ of $\mathrm{Mn}$ and lower concentrations of Selenium were recorded in farmed yellow perch when compared to the wild fish (Gonzalez et al., 2006). Calvi et al. (2006) observed higher levels of $\mathrm{Zn}$ in farm-raised eel and higher levels of $\mathrm{Ca}$ in the wild-caught samples. The variation in mineral composition of marine fish can occur due to seasonal and biological differences (species, size, dark/white muscle, age, sex and sexual maturity), area of catch, processing method, food source and environmental conditions (water chemistry, salinity, temperature and contaminants) (Rodrigo et al., 1998; Alasalvar et al., 2002; Turhan et al., 2004).

Based on the Recommended Daily Allowance (RDA), the dietary values (DV\%) for minerals were calculated for $100 \mathrm{~g}$ fish (Dayal et al., 2013; Mohanty et al., 2016). The DV\% indicates that consumption of

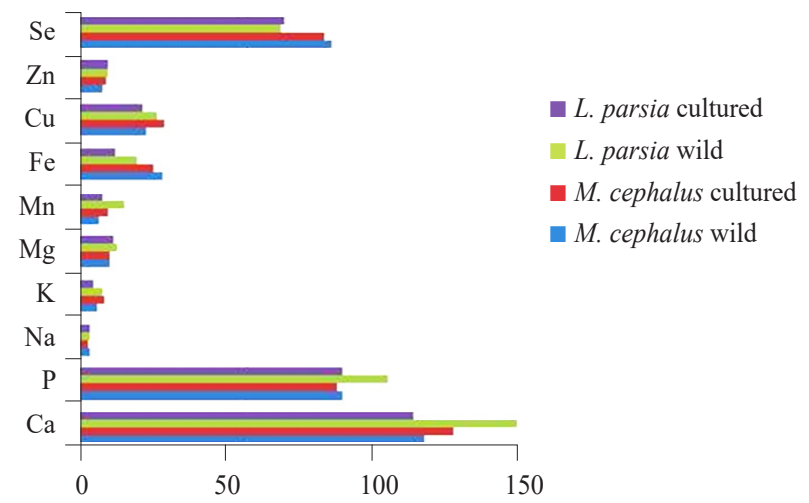

Fig. 2. Dietary values (\%) of minerals of Mugil cephalus and Liza parsia collected from wild and cultured populations 
Table 6. Mineral composition (mg $100 \mathrm{~g}^{-1}$ wet weight) of Mugil cephalus and Liza parsia collected from wild and cultured populations

\begin{tabular}{|c|c|c|c|c|c|c|c|c|c|c|}
\hline Particulars & $\mathrm{Ca}$ & $\mathrm{P}$ & $\mathrm{Na}$ & $\mathrm{K}$ & $\mathrm{Mg}$ & $\mathrm{Mn}$ & $\mathrm{Fe}$ & $\mathrm{Cu}$ & $\mathrm{Zn}$ & $\mathrm{Se}$ \\
\hline \multicolumn{11}{|l|}{ M. cephalus } \\
\hline Wild & $611.67^{\mathrm{a}} \pm 6.33$ & $467.37 \pm 3.92$ & $62.27^{b} \pm 2.33$ & $205.11^{a} \pm 4.42$ & $30.63 \pm 0.60$ & $0.24^{a} \pm 0.002$ & $4.18^{\mathrm{b}} \pm 0.131$ & $0.27^{a} \pm 0.013$ & $0.81^{a} \pm 0.032$ & $0.03 \pm 0.002$ \\
\hline Cultured & $663.61^{b} \pm 7.26$ & $458.14 \pm 6.80$ & $54.81^{\mathrm{a}} \pm 1.22$ & $279.29^{b} \pm 7.37$ & $30.48 \pm 0.30$ & $0.34^{b} \pm 0.017$ & $3.74^{\mathrm{a}} \pm 0.106$ & $0.34^{b} \pm 0.015$ & $0.98^{\mathrm{b}} \pm 0.035$ & $0.03 \pm 0.001$ \\
\hline \multicolumn{11}{|l|}{ L. parsia } \\
\hline Wild & $778.32^{y} \pm 5.68$ & $549.23^{\mathrm{y}} \pm 3.81$ & $70.45 \pm 1.35$ & $252.91^{y} \pm 4.32$ & $38.95^{\mathrm{y}} \pm 0.82$ & $20.54^{y} \pm 0.006$ & $2.89^{\mathrm{y}} \pm 0.057$ & $0.31^{y} \pm 0.016$ & $1.04 \pm 0.025$ & $0.02 \pm 0.002$ \\
\hline Cultured & $594.46^{x} \pm 5.14$ & $467.15^{x} \pm 5.65$ & $66.16 \pm 2.81$ & $169.68^{x} \pm 4.23$ & $35.16^{x} \pm 0.71$ & $10.29^{x} \pm 0.046$ & $1.86^{x} \pm 0.095$ & $0.25^{x} \pm 0.016$ & $1.05 \pm 0.037$ & $0.02 \pm 0.001$ \\
\hline
\end{tabular}

Means bearing different superscripts within the species differ significantly $(\mathrm{p}<0.05)$

$100 \mathrm{~g}$ fish could meet the requirements for $\mathrm{Ca}$ and $\mathrm{P}$. Mullet could provide $60-75 \%$ of dietary value for $\mathrm{Se}$ which is an important micronutrient that plays a major role in scavenging free radicals with its anti-oxidative properties and is an essential trace element required in small amounts for the basic functions of life and nutrition. The Se level in both the species of mullets was far below the FDA recommended safe level of $70 \mu \mathrm{g}$ (FDA, 2009). The lower Na content is another positive aspect of mullets, especially for hypertension patients. These mineral values are calculated for raw fish; however, dietary bioavailability is dependent on many factors. $\mathrm{Ca}, \mathrm{Mg}, \mathrm{Cu}$ and $\mathrm{Se}$ are relatively well absorbed, with reported fractional absorption values from mixed diets in human beings. The less absorbed trace elements include $\mathrm{Fe}, \mathrm{Zn}$ and $\mathrm{Mn}$, with absorption varying widely according to the nutritional status (including body reserves) of the individual and the composition of the diet (Tait and Hurrell, 1996).

\section{Economic analysis}

The economic analysis was carried out for testing the profitability of mullet polyculture (Table 7). The net income and benefit cost ratio (BCR) were better than the reported results at the Institute farm (Biswas et al., 2012). This is because of the higher production performance of mullets in the present study and the contribution of farm resources and labour by the farmer. Though the net income cannot be compared with that of shrimp aquaculture ( $~ 5-6$ lakhs per culture cycle), risks involved in the

Table 7. Economics of mullet polyculture in farmer's pond

\begin{tabular}{ll}
\hline Income and expenditure & $(₹)$ \\
\hline Fish seed cost $\left(@ 1 \mathrm{pc}^{-1}\right)$ & 11570 \\
Feed cost $(90 \mathrm{x} 1.1 \mathrm{FCR})$ & 48587 \\
Lease cost & 15000 \\
Fertilizers cost & 1500 \\
Energy cost & 2500 \\
Labour cost & 20000 \\
Total expenditure & 99157 \\
Sale of fish $\left(@ 140 \mathrm{~kg}^{-1}\right)$ & 176680 \\
Net income & 77523 \\
BCR & 1.78 \\
\hline
\end{tabular}

polyculture of finfish is minimal compared to shrimp farming. The profitability can be further increased by increasing the stocking density and productivity.

The results of this study indicate the techno-economic feasibility of mullet polyculture which could be considered as an ideal option for diversification of brackishwater aquaculture and it could serve as an alternative livelihood and provide nutritional security for the coastal population.

\section{Acknowledgements}

Authors express their sincere thanks to the Fisheries Division, Indian Council of Agricultural Research, New Delhi, India for supporting the ICAR-Outreach Activities. The support from Mr. T. Raghusekhar, a progressive Aqua-farmer for extending facilities to conduct culture demonstration in his farm is also gratefully acknowledged.

\section{References}

Alasalvar, C., Taylor, K. D. A., Zubcov, E., Shahidi, F. and Alexis, M. 2002. Differentiation of cultured and wild seabass (Dicentrarchus labrax): total lipid content, fatty acid and trace mineral composition. Food Chem., 79: 145-150.

APHA 2012. Standard methods for the examination of water and waste water. $22^{\text {nd }}$ edn. American Public Health Association, New York, USA.

AOAC 1997. Official methods of analysis, $18^{\text {th }}$ edn. Association of Official Analytical Chemists, Benjamin Franklin Station, Washington DC, USA.

Aubin, J., Baruthio, A., Mungkung, R. and Lazard, J. 2015. Environmental performance of brackishwater polyculture system from a life cycle perspective: A Filipino case study. Aquaculture, 435: 217-227.

Belitz, H. D., Grosch, W. and Schieberle, P. 2008. Textbook of food chemistry, Springer Verlag, Berlin, Heidelberg and New York, USA.

Biswas, G., Ananda Raja, R., De, D., Sundaray, J. K., Ghoshal, T. K., Anand, A., Kumar, S., Panigrahi, A., Thirunavakkarasu, A. R. and Ponniah, A. G. 2012. Evaluation of production and economic returns from two brackishwater polyculture systems in tide-fed ponds. J. Appl. Ichthyol., 28: 116-122. 
Calvi, A. M., Allinson, G., Jones, P., Salzman, S., Nishikawa, M. and Turoczy, N. 2006. Trace metal concentrations in wild and cultured Australian short-finned eel (Anguilla australis Richardson). Bull. Environ. Contam. Toxicol., 77: 590-596.

Cardona, L. 2006. Habitat selection by grey mullets (Osteichthyes: Mugilidae) in Mediterranean estuaries: the role of salinity. Sci. Mar., 70: 443-455.

Cox, D. H. and Karahadian, C. 1998. Evaluation of microbial counts, nucleotide degradation and sensory attributes of cultured and wild yellow perch (Perca flavescens) during refrigerated storage. J. Aqua. Food Product Technol., 7: 5-26.

Dayal, S. J., Ponniah, A. G., Imran Khan, H., Madhu Babu, E. P., Ambasankar, K. and Kumaraguru Vasagam, K. P. 2013. Shrimps - a nutritional perspective. Curr. Sci., 104: 1487-1491

Eldani, A. and Primavera, J. H. 1981. Effect of different stocking combinations on growth, production and survival of milkfish (Chanos chanos Forsskal) and prawn (Penaeus monodon Fabricius) in polyculture in brackishwater ponds. Aquaculture, 23: 59-72.

FAO 2012. The state of world fisheries and aquaculture 2012. Food and Agriculture Organisation of United Nations, Rome, $230 \mathrm{pp}$.

FDA 2009. Selenium and a reduced risk of site specific cancers, FDA2008Q0323. https://www.fda.gov/food/ ingredientspackaginglabeling/labelingnutritionucm 168527. htm (Accessed 23 April 2017).

Fuentes, A., Fernandez-Segovia, I., Serra, J. A. and Barat, J. M. 2010. Comparison of wild and cultured seabass (Dicentrarchus labrax) quality. Food Chem., 119: 1514-1518.

George, R. and Bophal, R. 1995. Fat composition of free living and farmed sea species: implications for human diet and sea farming techniques. Brit. Food J., 97: 19-22.

Giogios, I., Grigorakis, K. and Kalogeropoulos, N. 2013. Organoleptic and chemical quality of farmed meagre (Argyrosomus regius) as affected by size. Food Chem., 141: 3153-3159.

Gonza'leza, S., Flicka, G. J., O'Keefea, S. F., Duncana, S. E., McLeanb, E. and Craigc, S. R. 2006. Composition of farmed and wild yellow perch (Perca flavescens). J. Food Comp. Anal., 19: 720-726.

Gonzalez-Murcia, S., Marin-Martinez, C. and Ayala-Bocos, A. 2012. Intertidal rockpool ichthyofauna of El Pital, La Libertad, El Salvador. Check List 8: 1216-1219.

Grigorakis, K. and Alexis, M. 2005. Effects of fasting on the meat quality and fat deposition of commercial-size farmed gilthead sea bream (Sparus aurata L.) fed different dietary regimes. Aquac. Nutr., 11: 341-344.

Grigorakis, K., Alexis, M. N., Taylor, K. D. A. and Hole, M. 2002. Comparison of wild and cultured gilthead sea bream (Sparus aurata): composition, appearance and seasonal variations. Int. J. Food Sci. Tech., 37: 477-484.

Grigorakis, K., Fountoulaki, E., Vasilaki, A., Mittakos, I. and Nathanailides, C. 2011. Lipid quality and filleting yield of reared meagre (Argyrosomus regius). Int. J. Food Sci. Technol., 46: 711-716.

Haard, N. F. 1992. Control of chemical composition and food quality attributes of cultured fish. Food Res. Int., 25: 289-307.

Karakoltsidis, P. A., Zotos, A. and Contantindes, S. M. 1995 Composition of the commercially important mediterranean finfish, crustaceans and molluscs. J. Food Comp. Anal., 8: $258-273$

Le Loc, H. F., Durand, D., Diop, K. and Panfili, J. 2015. Spatiotemporal isotopic signatures reveal that two sympatric West African mullet species do not feed on the same basal production sources. J. Fish Biol., 86: 1444-1453.

Lovatelli, A. 1990. Regional sea farming development and demonstration project. Regional seafarming resources atlas. FAO Corporate Document Repository, Network of Aquaculture Centres in the Asia-Pacific, Bangkok, Thailand.

Marais, J. F. K. and Erasmus, T. 1977. Body composition of Mugil cephalus, Liza dumerili, Liza richardsoni and Liza tricuspidens (Teleostei; Mugilidae) caught in the Swartkops Estuary. Aquaculture, 10: 75-86.

Menezes, M. E. S., Lira, G. M., Omena, C. M. B., Freitas, J. D. and Sant'Ana, A. E. G. 2008. Proximate composition, cholesterol and fatty acid of the fished species of estuarino Tainha (Mugil cephalus) and Camurim (Centropomus undecimalis) from Mundau Lagoon, $\mathrm{Al} / \mathrm{Brazil}$. Rev. Inst. Adolfo Lutz., 67: 89-95.

Milstein, A. 2005. Polyculture in aquaculture, Animal Breeding Abstracts. CABI Publishing, p. 15-41.

Mohanty, B. P., Sankar, T. V., Ganguly, S., Mahanty, R., Anandan, R., Chakraborty, K., Paul, B. N., Sarma, D., Syama Dayal, J., Mathew, S., Asha, K. K., Mitra, T., Karunakaran, D., Chanda, S. Shahi, N., Das, P., Akhtar, M. S., Vijayagopal, P. and Sridhar, N. 2016. Micronutrient composition of 35 food fishes from India and their significance in human nutrition. Biol. Trace Elem. Res., 174: 448-458.

Morshita, T., Uno, K., Araki, T. and Takahashi, T. 1989. Comparision of the fatty acid compositions in cultured red seabream differing in the localities and culture methods and those in wild fish. Nippon Suisan Gakkaishi, 55: 847-852.

Nash, C. E. and Shehadeh, Z. H. 1980. Review of breeding and propagation techniques for grey mullet, Mugil cephalus L. In: ICLARM studies and reviews. International Center for Living Aquatic Resources Management, Manila, Philippines

Nettleton, J. A. and Exler, J. 1992. Nutrients in wild and farmed fish and shellfish. J. Food Sci., 57: 257-260.

Poli, B. M., Parisi, G., Zampacavallo, G., Mecatti, M., Lupi, P., Gualtieri, M. and Franci, O. 2001. Quality outline of European 
seabass (Dicentrarchus labrax) reared in Italy: shelf life, edible yield, nutritional and dietetic traits. Aquaculture, 202: 303-315.

Rheman, S., Islam, M. L., Shah, M. M. R., Mondal, S. and Alam, M. J. 2002. Observation on the fecundity and gonadosomatic index (GSI) of Grey mullet Liza parsia (Ham.). J. Biol. Sci., 2: 690-693.

Rodrigo, J., Ros, G., Periago, M. J., Lopez, C. and Ortuno, J. 1998. Proximate and mineral composition of dried salted roes of hake (Merlucccius merluccius, L.) and ling (Molva molva, L.). Food Chem., 63: 221-225.

Shofiquzzoha, A. F. M., Islam, M. L. and Ahmed, S. U. 2001. Optimisation of stocking rates of shrimp (P. monodon) with brackishwater finfish in a polyculture system. J. Biol. Sci., 1: 694-697.

Tait, F. S. and Hurrell, R. F. 1996. Bioavailability of minerals and trace elements. Nutr. Res. Rev., 9: 295-324.
Talwar P. K. and Jhingran, A. 1991. Inland fishes of India and adjacent countries, Oxford and IBH publishing Co. Pvt. Ltd, New Delhi. p. 889-904.

Turhan, S., Ustun, S. N. and Altunkaynak, B. 2004. Effect of cooking methods on total and heme iron contents of anchovy (Engraulis encrasicholus). Food. Chem., 88: 169-172.

Young, G. C. and Potter, I. C. 2002. Influence of exceptionally high salinities, marked variations in fresh-water discharge and opening of estuary mouth on the characteristics of the ichthyofauna of a normally closed estuary. Estuarine Coastal Shelf Sci., 55: 223-246.

Zhao, F., Zhuang, P., Song, C., Shi, Z. and Zhang, L. 2010. Amino acid and fatty acid compositions and nutritional quality of muscle in the pomfret, Pampus punctatissimus. Food Chem., 118: 224-227. 